\title{
SUPER MARIO STRIKES BACK: ANOTHER MOLINIST REPLY TO WELTY'S GUNSLINGERS ARGUMENT
}

\author{
Tyler DALTON MCNABB*
}

Houston Baptist University

\begin{abstract}
Molinists generally see Calvinism as possessing certain liabilities from which Molinism is immune. For example, Molinists have traditionally rejected Calvinism, in part, because it allegedly makes God the author of sin. According to Molina, we 'should not infer that He is in any way a cause of sin'. However, Greg Welty has recently argued by way of his Gunslingers Argument that, when it comes to God's relationship to evil, Molinism is susceptible to the same liabilities as Calvinism. If his argument is successful, he has undercut, at least partially, justification for believing in Molinism. While I concede that Welty's argument is successful in that it does undercut some justification for believing in Molinism, this concession does not entail that, as it relates to the problem of evil, the Calvinist and the Molinist are in the same epistemic position. In this article, I argue that, when it comes to God's relationship to evil, the Molinist is in a superior epistemic situation to the Calvinist. I do this in two steps. First, I argue for what I call the Robust Felix Culpa Theodicy. Second, I argue that the Robust Felix Culpa Theodicy is incompatible with Calvinism.
\end{abstract}

KEY WORDS: Gunslingers, problem of evil, Molinism, Felix Culpa theodicy, Principle of Alternative Possibilities

All orthodox Christian traditions deny that God is the author of evil insofar as God is the originator of sin or insofar as God has evil intentions or actions. For example, the Catechism of the Catholic Church states,

Angels and men, as intelligent and free creatures, have to journey toward their ultimate destinies by their free choice and preferential love. They can therefore go astray. Indeed, they have sinned. Thus, has moral evil, incommensurably more harmful than physical evil, entered the world. God is in no way, directly or indirectly, the cause of moral evil. He permits it, however, because he respects the freedom of his creatures and, mysteriously, knows how to derive good from it (311).

* TYleR DALTON MCNABB (PhD 2016, University of Glasgow) is Assistant Professor of Philosophy at Houston Baptist University. Email: tmcnabb@hbu.edu. 
Likewise, the Westminster Confession of Faith contends that 'God from all eternity did by the most wise and holy counsel of his own will, freely and unchangeably ordain whatsoever comes to pass; yet so as thereby neither is God the author of sin; nor is violence offered to the will of the creatures, nor is the liberty or contingency of second causes taken away, but rather established' (3). Finally, the Baptist tradition echoes the Westminster tradition, as the Second London Baptist Confession of Faith proclaims:

God hath decreed in himself, from all eternity, by the most wise and holy counsel of His own will, freely and unchangeably, all things, whatsoever comes to pass; yet so as thereby is God neither the author of sin nor hath fellowship with any therein; nor is violence offered to the will of the creature, nor yet is the liberty or contingency of second causes taken away, but rather established; in which appears His wisdom in disposing all things, and power and faithfulness in accomplishing His decree (3.1).

However, there are varying positions that one can take when it comes to understanding God's relationship to evil. For example, though Jonathan Edwards argues that God is not the author of sin in the aforementioned sense, he does argue that God is the author of sin in another sense, namely insofar as he is the 'disposer and orderer of sin' (Edwards 1957: 399; cf. Welty 2016: 57). God is the author of sin by way of his predetermining that sin or evil would indeed enter into the world. For Edwards, upon God's determining that a subject sin, it is not such that the subject can bring it about that she will not sin. God's disposing of the subject is sufficient for bringing about all of her actions.

Luis de Molina offers a different approach. Molina bifurcates the category of God's causation into weak causation and strong causation (MacGregor 2015: 109-10). These terms are defined as follows:

Weak Causation: Roughly, for subject $S$ to weakly cause event $E, S$ sustains subject $S^{*}$ 's causal powers in order for $S^{*}$ to bring about $E$.

Strong Causation: Roughly, for $S$ to strongly cause event $E, \mathrm{~S}$ directly causes $E$.

Molina argues that God's weak causation is analogous to the power of the sun: though it is a necessary condition for agents to carry out their agency, it is clearly not a sufficient condition for an agent to perform an action. And it is because of this, that, though God is the cause of everything in some sense, we 'should not infer that He is in any way a cause of sin' (Molina 1988: 178-9).

Molinists have typically argued that one of the many reasons one should prefer their system to the traditional compatibilist version of Calvinism is that Molinism lacks certain liabilities or problems which are unavoidable on traditional Calvinism (Keathley 2010: 4). [For non-traditional versions of 
Calvinism, see Crisp (2014).] While both agree that God is ultimately the cause of everything in at least a weak sense, the Molinist can 'one-up' the Calvinist by rejecting the notion that God strongly causes evil. But is this a good strategy for the Molinist?

In his article 'Molinist Gunslingers: God and the Authorship of Sin', Greg Welty argues that if Calvinism entails certain liabilities, Molinists' own model of divine causation is sufficiently analogous such that it inherits all of the alleged Calvinist liabilities (Welty 2016: 57). Welty's argument takes the shape of modus ponens and proceeds as follows:

(1) If divine causation in Molinist providence is sufficiently analogous to sufficient causation, then Molinism inherits all of the Calvinist liabilities with respect to divine authorship of sin, responsibility, and blame.

(2) Molinist providence is sufficiently analogous to sufficient causation.

And so it follows that:

(3) Molinism does inherit any Calvinist liabilities with respect to divine authorship of sin, responsibility, and blame (Welty 2016: 60).

Welty's strategy for making this argument plausible is by articulating his 'gunslinger' cases.

The Ordinary Gun Case can be summarized as follows. Imagine I take a gun, aim it, and pull the trigger, as I take the life of an innocent individual. In this case, it seems obvious that I am the one who bears the moral responsibility for murdering the subject. The gun and the bullet are not seen as blameworthy, but I clearly am. I am the only one who possesses agency, and it was through this agency that I took an innocent life. As Welty states, in this case 'I am the author of sin' (Welty 2016: 61).

Molinists will argue that this case constitutes an analogue to the way Calvinists view God and evil. The bullet is analogous to a human person who lacks the ability to do otherwise, and God is represented by the person shooting the bullet into an intended direction. Prima facie, it seems like this view of God makes God morally reprehensible. Given that all of this is the case, we should reject Calvinism for Molinism. While this line of reasoning might seem initially plausible, Welty argues that the Molinist is in no better of a situation than the Calvinist. He utilizes the Bullet Bill Case in an attempt to help demonstrate this.

The Bullet Bill Case can be summarized as follows. Imagine that I again pull out a gun. However, this time when I take aim and fire, what comes out is not a regular old bullet; rather, a Bullet Bill (from the world of Super Mario) is created and fired. Now it is important to mention that Bullet Bill has personhood, agency, and libertarian freedom. Thus, assuming that I have 
knowledge of the relevant counterfactuals of creaturely freedom (CCFs), wouldn't I still be morally blameworthy for my actions if I fire Bullet Bill at $S$, fully knowing that under these conditions Bullet Bill will freely choose to kill $S$ ? Imagine, as the person firing the gun, I go into a building and fire dozens of Bullet Bills, such that 'the next trigger pull would create Bullet Bill A, who (if created) would freely fly out of the barrel and kill Angie, that the next trigger pull would create Bullet Bill B, who (if created) would freely fly out of the barrel and kill Beth, that the next trigger pull would create Bullet Bill C and kill Caroline, and so on' (Welty 2016: 64). Wouldn't I be morally reprehensible for doing all of this? As Welty states,

But does Bullet Bill's individual responsibility somehow lessen my responsibility, the one who aims and shoots the Bullet Bill gun and thereby kills three people in rapid succession? I don't see how. It just doesn't strike me as plausible that the man who wields the Bullet Bill gun is any less responsible simply because he didn't directly cause Bullet Bill to do what he did (Welty 2016: 65).

So, there does not seem to be a clear distinction between the two gun cases, and, if the Molinist position is supposed to be well represented by the Bullet Bill case, then it would follow that we have good reason to think that (2) of Welty's argument is plausible.

There are a number of approaches that a Molinist could take in responding to Welty's argument. One approach might be to argue that, for some reason, the Bullet Bill Case is disanalogous to what happens on Molinism. (My colleague Kenneth Keathley takes this approach in the previous article.) For the purposes of my article, I will not take this position here. Rather, I will actually concede that Welty's argument is sound. In fact, I think that God, à la Edwards, needs to be the author of sin. However, while I concede that Welty's argument is successful in undercutting some justification for believing in Molinism, this concession does not entail that, as it relates to the problem of evil, the Calvinist and the Molinist are in the same epistemic position. In this article, I will argue that, when it comes to God's relationship to evil, the Molinist is in a superior epistemic situation to the Calvinist. I will do this in two steps. First, I will argue for what I call the Robust Felix Culpa Theodicy. Second, I will argue that the Robust Felix Culpa Theodicy is incompatible with Calvinism. Before I can proceed, however, it is first necessary to articulate the traditional Felix Culpa theodicy.

\section{The Traditional Felix Culpa Theodicy}

In 'Supralapsarianism, or «O Felix Culpa’, Alvin Plantinga advocates an exclusively Christian approach to the problem of evil (Plantinga 2004: 125). Plantinga's approach has been entitled the Felix Culpa theodicy. The theodicy goes as follows: In wanting to actualize a world from the best set of 
possible worlds, God would actualize a world that contained the events of the Incarnation and Atonement. Worlds where God becomes man in order to redeem humanity from its sins are greater than worlds in which there is no need for the Incarnation and Atonement. Given that worlds containing the Incarnation and Atonement are worlds that assume the existence of sin and suffering, on Felix Culpa God permits sin and suffering to exist for a greater good. Thus, overall, Plantinga thinks it is extremely probable that evil would exist on theism.

While I have defended the traditional Felix Culpa theodicy elsewhere (McNabb and Baldwin forthcoming), I now think that this theodicy, as articulated by Plantinga, is incomplete. I will now transition to arguing for what I call the Robust Felix Culpa Theodicy.

\section{Robust Felix Culpa and Super Mario Strikes Back}

Not only would all the worlds in the set of best possible worlds contain the events of the Incarnation and Atonement, but these events would also need to come about through libertarian agents. Compare the following scenarios:

\section{Story 1}

God creates a world full of human agents, whom though he loves, he determines (in a compatibilist sense) that they go astray. While the human agents lack the ability to choose the good and return to God, God the Son, nonetheless, becomes man and dies for humanity's sin. Upon God the Father raising God the Son from the dead, God's Spirit irresistibly draws some of those who went astray and forces them into union with the Son.

\section{Story 2}

God creates a world full of human agents, whom though he loves, he permits them to not reciprocate that love back to him. While the human agents refuse to choose the good and return to God, God the Son, nonetheless, becomes man and dies for humanity's sin. Upon God the Father raising God the Son from the dead, God's Spirit draws all of humanity to himself, and an uncountable number of human agents finally recognize their sin, freely repent, and enter into union with the Son.

Story 2, intuitively to me, seems to be a better world than Story 1 . Story 2 is much more of a classic love story, where though a man freely lets his lover leave him, he does everything he can to convince her to freely return to the union that she left behind. Story 1, on the other hand, lacks a movie or novel to which it could be compared. Imagine the story of a man who forces his lover to leave him, and then he spends the rest of the story making it such that the woman could do nothing but return to their union. This story, if not morally appalling, is minimally less great-making than Story 2. 
Inspired by Welty's Gunslingers Argument, I'd like to formulate another scenario which aims to show that Story 2 is a better story than Story 1 .

\section{Super Mario 1}

I just bought the latest Super Mario game. As I begin to play it, I realize that Nintendo made the game such that, literally, it was impossible for me to lose. I will start off on level one, and I will continue to progress until I reach the final battle with Bowser. I might have setbacks within the game; for example, I might lose lives after getting hit by shells or perhaps after getting pounded by Bowser. But ultimately it is impossible for me to lose to Bowser and his minions. The rescue of Princess Peach is inevitable.

\section{Super Mario 2}

I just bought the latest Super Mario game. As I begin to play it, I realize that Nintendo made the game such that it is possible that I would never actually beat the game. Other than starting off at level one, everything else is indeterminate. However, due to my skill, with much excitement, I do progress through the game, knowing full well that it could be such that I will not make it past the next level. However, it does turn out to be the case that I ultimately beat Bowser and his minions and rescue Princess Peach.

Again, my intuitions are clear here. Super Mario 2 seems like a greater game than Super Mario 1. The possibility of your making the wrong move and never being able to beat the game are part of the game's greatness. Similar to the comparison of the romance scenarios, there is something intrinsically great about a story where the conclusion of the story is happily resolved without any strong-arming or coercion.

It is these sorts of considerations which make abundantly clear that Story 2 possesses certain intrinsically great-making properties that Story 1 lacks. And if the success of the Felix Culpa theodicy is predicated on the idea that God would actualize the best sort of world that he could, then God would only actualize worlds where there existed libertarian agents.

\section{A Gamer's Praiseworthiness and Blameworthiness}

In addition to libertarian freedom being necessary in order to capture a particular great-making feature as discussed above, libertarian freedom is also needed to make sense of the agent's praiseworthiness and blameworthiness within the story. Let's return to the Super Mario Strikes Back Scenario to further flesh this out.

Do I deserve praise or recognition for beating a video game in which it is impossible for me to not win? Surely, such praise would be suspicious. Much less suspicious it would be to praise me for beating a game in which it was possible that I could lose. It is plausible to think that most would be inclined 
to think this way, at least, prima facie. Behind this inclination, I think, is something like the following principle:

The Praiseworthy and Blameworthy Principle (TPBP): In order for subject $S$ to be either praiseworthy or blameworthy, $S$ has to have done an action which she could have refrained from doing.

Given a Reidian epistemology, if our prima facie intuition leads us to affirm TPBP, then we should hold to it unless we have a defeater for it. But is there a defeater for holding to this principle? If there is a defeater for it, it would likely come from counterexamples to the Principle of Alternative Possibilities (PAP). [Roughly, its thesis is that in order for subject $S$ to be morally responsible for her action $A, S$ had to have the ability to do $A$ or $\neg A$.] Such examples are better known as Frankfurt examples.

According to John Martin Fischer, Frankfurt-type examples are examples which 'contain a fail-safe mechanism that does not actually play any role in the relevant agent's deliberations, choices, and behavior, but whose presence ensures that the agent deliberates, chooses, and behaves just as he actually does' (Fischer 2011: 244). To further elucidate what Frankfurt examples are, I will now give a relevant example aimed at discrediting my Super Mario Strikes Back Scenario.

Imagine that unbeknownst to me, as I am in line to buy the new Mario game, the creators of the game insert a secret device into my brain which they can activate to take over my brain at any time. Now, let's suppose that I am playing Mario and I come to the final level. I have to push 'A' in order to beat the game and if I push 'B' I will actually get a 'game over'.

Given that the creators of the game have a vested interest in me beating the game, they will make sure that I push 'A'. So, if my thumb started to go down on 'B' they would activate the device in my brain in order that I stop and click 'A'. But let us say that I naturally choose 'A' and the creators of the game do not intervene. Would not I still be praiseworthy even if it was not possible that I could click 'B' and get a 'game over'?

Of course, through reflection on this possibility, the soundness of TPBP becomes less clear. But there have been responses to Frankfurt counterexamples.

For example, William Hasker argues that while an agent in a relevant case would lack the power to do otherwise, the agent would still have within her power the ability to make a decision to act or not act, and it is within this decision to act or not that the responsibility of the agent lies (Hasker 1999: 90).

If the decision to act is robust enough to ground praiseworthiness and blameworthiness, then it does seem that TPBP remains plausible. 


\section{Middle Knowledge to the Rescue?}

There is a more recent Frankfurt-styled argument that Michael Bergmann has developed which, ironically, utilizes counterfactual knowledge. If Bergmann is successful, the Molinist will be left with the option of denying the possibility of middle knowledge (which she won't want to do if she is to remain a Molinist) or deny TPBP. If she denies the latter, the second part of my response to Welty should be seen as unsuccessful.

Instead of fallible observers who watch someone's decisions via some sort of sneaky mechanism, Bergmann argues for the possibility of an agent who possesses counterfactual knowledge over a relevant subject. In his scenario, he calls that subject Jones. Bergmann lays out his scenario in the following way:

A. If from time $t^{*}$ until $t$ Jones were in circumstances $K$ and Demon didn't take away Jones' powers at $t$ with respect to $V^{l}$ [a volition to pull the trigger of the gun in Jones' hand], then Jones would agent-cause $V^{l}$ at $t$.

B. If $A$ were false, Demon would know it (long before $t$ ) and would take away Jones' powers at $t$ with respect to $V^{l}$ (Bergmann 2002: 467-9; cf. Flint 2002: 479).

To summarize, the idea is something like this: Demon knows that if Jones were in circumstance $K$, Jones would freely agent-cause $V^{l}$ at $t$. If the counterfactuals of Jones' freedom were such that Jones would not have agentcaused $V^{l}$, then Demon would have intervened. So, in this case, Jones literally lacks the ability to not agent-cause $V^{l}$, and yet he still is responsible for his agent-causing $V^{1}$ at $t$. This scenario, then, cannot simply be ignored by way of centering Jones' responsibility on his decision to do $V^{l}$ or not do $V^{l}$, as Jones isn't in the situation where he could have made any alternative decisions. So, does not this count as a counterexample to TPBP?

I think there is at least one way to avoid Bergmann's clever response while remaining a committed Molinist. What Bergmann seems to forget is that a lot of libertarians advocate a Reidian theory of agency. Roughly, its thesis is that in order for $S$ to agent-cause $E, S$ must have the power to both cause $E$ and refrain from causing $E$. It does not make sense to say that $S$ has the power to cause $V^{l}$, but yet she does not have the ability to refrain from causing $V^{l}$. As Flint observes, 'Bergmann's counterexample requires that Demon leave Jones with the power to cause $V^{l}$, but not with the power to refrain from causing it. And that, Reid and company would insist, is simply impossible: 'Power to produce any effect, implies power not to produce it' (Flint 2002: 483).

Now, of course this sort of response would in principle prevent any sort of Frankfurt case from even getting off the ground and, thus, it likely will not appeal to those who aren't already convinced of TPBP. However, for 
those who are already advocates of TPBP, this response should be seen as sufficient to block a Frankfurt-styled defeater. This being the case, given its initial prima facie plausibility, I see no reason to reject TPBT. And given that something like TPBT is true, it seems plausible that the greatest set of worlds which could be actualized would include worlds which tell the Felix Culpa story through agents who can be both praised and blamed for their actions. This consideration seems to give Molinism the upper hand over Calvinism in making sense of God and his relationship to evil.

\section{Conclusion}

After articulating and then conceding the main point of the Gunslingers Argument, I argued that it doesn't follow that Calvinism fares better than Molinism as it pertains to God and his relationship to evil. I did this by arguing for what I called the Robust Felix Culpa Theodicy. Given that a Robust Felix Culpa Theodicy is incompatible with Calvinism, it seems that Molinism still has the advantage over Calvinism, even granting Welty's Gunslingers.

\section{Bibliography}

Bergmann M (2002) Molinist Frankfurt-Style Counterexamples and the Free Will Defense. Faith and Philosophy 19(4): 462-78.

Crisp O (2014) Deviant Calvinism: Broadening Reformed Theology. Minneapolis, $\mathrm{MN}$ : Fortress.

Edwards J (1957) Freedom of the Will. In Ramsey P (ed) Works of Jonathan Edwards, volume 1. New Haven, CT: Yale University Press.

Fischer JM (2011) The Oxford Handbook of Free Will. Kane R (ed) Oxford: Oxford University Press.

Flint TP (2002) On Behalf of the Pap-ists: A Reply to Bergmann. Faith and Philosophy 19(4): 479-84.

Hasker W (1999) The Emergent Self. Ithaca, NY: Cornell University Press.

Keathley K (2010) Salvation and Sovereignty: A Molinist Approach. Nashville, TN: B \& H Academic.

MacGregor KR (2015) Luis de Molina: The Life and Theology of the Founder of Middle Knowledge. Grand Rapids, IL: Zondervan.

Molina L (1988) On Divine Foreknowledge: Part IV of the Concordia. Freddoso AJ (trans). Ithaca, NY: Cornell University Press.

Welty G (2016) Molinist Gunslingers: God and the Authorship of Sin. In Alexander DE and Johnson DM (eds) Calvinism and the Problem of Evil. Eugene, OR: Pickwick, pp. 56-77. 